\title{
Field Evaluation of Different Chemical Compounds in Attracting the Mediterranean Fruit Fly, Ceratitis capitata Wied: (Diptera, Tephritidae) Using Makkar and El-Abbassi Plastic Trap \\ Makkar, A. W. ; T. S. El-Abbassi and M. M. El-Metwally \\ Plant Protection Research Institute, ARC. Dokki, Giza , Egypt
}

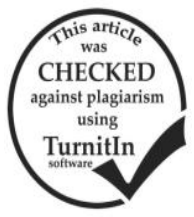

\section{ABSTRACT}

Field experiments were conducted to evaluate the efficiency of Makkar and El-Abbassi plastic trap loaded with four attractant sachets against the Mediterranean fruit fly Ceratitis capitata (Wied). Trials were carried out in two different locations, at El-Santa, Gharbia Governorate within the period from November $24^{\text {th }} 2015$ till January $17^{\text {th }}$ 2016, and at Aga, Dakahlia Governorate within the period from February $29^{\text {th }} 2016$ till April $26^{\text {th }} 2016$. The two locations were cultivated with citrus tress. Results revealed that, Makkar and El-Abbassi trap loaded with sachets mounted with the three component lures (Ammonium acetate + Putrescine + Trimethylamine) ), treatment (D) captured more flies where compared with the other treatments throughout the period of experiment (16 weeks), meanwhile, the lowest cumulated number of captured flies was in traps baited with treatment (A), (Ammonium acetate). Treatment (C) (Ammonium acetate + Diammonium phosphate + Trimethylamine) captured reasonable high number of flies when compared with the other treatments (A and B). Data showed also that the highest percentages of captured females throughout four periods were in treatment (D) (92.2\%). Statistical analysis showed non significant differences between treatment (D) and treatment (C). Results obtained from this study revealed that C. capitata could be controlled by applying mass trapping technique, treatment (D) a better option for mass trapping.

Keywords: Mediterranean Fruit Fly, Ammonium acetate, Diammonium phosphate, Putrescine and Trimethylamine

\section{INTRODUCTION}

The Mediterranean Fruit Fly, Ceratitis capitata (Wied) is one of the world's most destructive and injurious fruit pests. It is widely distributed and the list of its host range is long and diverse (White and Elson-Harris 1994). Cohen and Yuval (2000) pointed out that Ceratitis capitata is polyphagous and as such uses the various hosts in its environment as stepping stones, moving from one to another as fruit mature throughout the season. It is high priority quarantine pest, therefore intensive control applications against this pest in the fruit growing areas are applied. Recently, research and development of effective control methods as alternative to chemical control are needed. These methods could include the use of traps baited with the female targeted and male targeted lures (Papadopoulas et al., 2001; Broughton and De Lima, 2002; Heath et al., 2004 and Tóth et al.,2004).

Tephritids use both visual and chemical signals to locate and access habitat, adult food, oviposition sites and mating resources. Plant chemical cues play a crucial role in mediating host finding and oviposition (Fletcher and Prokopy, 1991). Epsky and Heath (1998) and Hull and Cribb (2001) revealed that, ammonia releasing substances play an important role in fruit fly attraction to food sources. Piñero et al., (2015) showed that ammonia and its derivatives are used by female fruit flies (Diptera: Tephritidae) as volatile cues to locate protein-rich food needed to produce their eggs. Heath et al., (1997) stated that addition of trimethylamine to traps baited with ammonium acetate and putrescine increased capture of C.capitata. Ros, et al., (1997) found that combination of the three components putrescine, ammonium acetate and trimethylamine slow release membranes glued inside the tephri fly catcher was Mosquero mixing and more attractive to $C$. capitata females. Leblance et al,. (2010) stated that Biolure, a synthetic food attractant for $C$. capitata which composed of three chemicals (ammonium acetate, trimethylamine hydrochloride and putrescine) attracted very few predators, parasitoids or pollinators. Makkar, et al., (2015) evaluated Makkar and El-Abbassi trap and its modifications for attracting adult males of peach fruit fly. In the same trend, Makkar, et al., (2016) evaluated Makkar and El-Abbassi trap in attracting the (MFF) C. capitata as an alternative to standard traps. So, the objective of the present work was the evaluation of fruit fly attractants for $C$. capitata under Egyptian condition, and assessment of the cost effectiveness of the various products.

\section{MATERIALS AND METHODS}

\section{Experimental locations:}

The present experiment was carried out in two different locations. First location was at El-Santa district, Gharbia governorate, where about 25 feddans were cultivated with novel orange. Second location was carried out at Aga district, Dakahlia Governorate, where about 20 feddans were planted with valencia orange (Citrus sinensis var. Valencia).

\section{Duration and conditions of trials:}

Evaluation of four tested attractant materials started from date of hanging traps in of November $24^{\text {th }} 2015$ till April $26^{\text {th }} 2016$ and divided into four periods (A, B, C, D). Maximum, minimum and average of temperature and relative humidity in each period, were recorded.

A- First period: from November $24^{\text {th }}$ till December $22^{\text {th }}$ 2015

Avg. Temp. $($ Min-Max $)=16.6(12.9-20.4)$.

Avg. RH. (Min-Max )= 53.7 (33.6-73.7).

B- Second period: from December $22^{\text {th }} 2015$ till January $17^{\text {th }} 2016$

Avg. Temp. $($ Min-Max $)=13.8$ (9.2-18.4).

Avg. RH. (Min-Max ) $=54.9(36.4-73.5)$.

C- Third period: from February $29^{\text {th }} 2016$ till March $28^{\text {th }} 2016$

Avg. Temp. $($ Min-Max $)=17.3(12.1-22.4)$.

Avg. RH. (Min-Max $)=61.5(42.8-80.2)$.

D- Fourth period: from March $30^{\text {th }}$ till April $26^{\text {th }} 2016$

Avg. Temp. $($ Min-Max $)=20.1$ (13.9-26.3).

Avg. RH. (Min-Max $)=63.2(43.8-82.6)$.

Evaluation extended for four weeks per each period.

Description of experimental plot:

The experimental area in each location was divided into four blocks, each of 4 feddans and about 0.5 feddan was left between every two blocks. Each block was 
devoted for Makkar \& El-Abbassi trap ( 4 traps (replicates) were prepared with four treatments. These traps were arranged in complete randomized block design, and hanged at a height of $150-170 \mathrm{~cm}$ above ground on the southern external branches of trees. The distance between each two successive traps was 40 meters. Traps were cheeked and rotated per week. Dead and captured males and/or females were counted and removed after each trap check.

Trap type was used to catch medfly:

The second modified shape of Makkar \& ElAbbassi trap was used ( Makkar et al., (2015). A film of insecticide Deltamthrine $(0.2 \mathrm{mg}$.) was smeared on the lower side of trap lid which acted as a killing agent (retention system), El- Abbassi et al., (2017) in press.

\section{Tested attractant materials:}

1- Ammonium acetate (AA)

2- Diammonium phosphate (DAP)

3- Putrescine (PT)

4- Trimethylamine (TMA)

Each treatments was used as follows:

All treatments were prepared as a new wetted lure bag.

A- (AA)

B- $(\mathrm{AA})+(\mathrm{DAP})+(\mathrm{PT})$

C- $(\mathrm{AA})+(\mathrm{DAP})+(\mathrm{TMA})$

D- $(\mathrm{AA})+(\mathrm{PT})+(\mathrm{TMA})$

These traps and lures were innovated by Research

\& Development Department- National Area- wide Fruit Flies Extermination Program.

\section{Statistical analysis:}

Number of captured males and/or females were recorded; values of captured flies per trap per day (CTD) and

percentages of males and/or females were calculated. Statistical analysis was fulfilled using a completely randomized design.

\section{RESULTS}

Data in the first location show response of Mediterranean fruit fly, C. capitata to different attractant materials when inspected under field conditions in navel orange at El-Santa district, Gharbia governorate. Data represented in Table (1) show cumulated mean number of medflies (males and/or females) captured/trap/week; at the first period (November 24 $4^{\text {th }}$ till December $22^{\text {th }} 2015$ ). Results showed that, Makkar \& El-Abassi trap with three component lure Ammonium acetate (AA) + Putrescine (PT) + Trimethylamine (TMA), treatment (D) captured (538 flies) with mean $(134 \pm 72.96)$ more than the other treatments within this period. Treatment (C) ((AA) + Diammonium phosphate (DAP) + (TMA)) captured higher number of flies when compared with two treatments (A) and (B). In all treatments females were highly attracted than males. Also data presented in Table (1) clearly show that the highest percentage of captured females at the first period in treatment (D) was $82.3 \%$ while, the highest percentage of captured males in treatment (A) was $20 \%$. In the same time, data clearly showed that there was non significant differences between treatment (D) and treatment (C), while, there was significant difference in mean number of captured flies between treatment $(\mathrm{D}, \mathrm{C})$ and treatments $(\mathrm{A}, \mathrm{B})$, where the computed $(\mathrm{F})$ values was 7.5 and L.S.D. $=69.2$. The climatic conditions recorded in this period, characterized by Avg, daily temperature $\left(16.6^{\circ} \mathrm{C}\right)$, and Avg. relative humidity $(\mathrm{RH})$ $53.7 \%$.

Table 1. Mean number, CTD values and percentages of captured medfly adults (Males and/or females) inside Makkar \& El-Abbassi traps throughout a period of four weeks in navel orange at the first period (November $24^{\text {th }}$ till December $\left.22^{\text {th }}\right) 2015$

\begin{tabular}{|c|c|c|c|c|c|}
\hline \multirow{2}{*}{ Treatments } & \multirow{2}{*}{$\begin{array}{c}\text { Means } \\
\pm \text { SD }\end{array}$} & \multirow{2}{*}{ CTD } & \multicolumn{2}{|c|}{ \% of captured medfly adults } & \multirow{2}{*}{$\begin{array}{c}\text { Total } \\
\text { of males and females }\end{array}$} \\
\hline & & & $\overline{0}$ & 9 & \\
\hline$\overline{A-(A A)}$ & $8.75 \pm 7.6 \mathrm{a}$ & 0.31 & 20.0 & 80.0 & 35 \\
\hline $\mathrm{B}-(\mathrm{AA})+(\mathrm{DAP})+(\mathrm{PT})$ & $7.75 \pm 2.9 \mathrm{a}$ & 0.28 & 19.4 & 80.6 & 31 \\
\hline $\mathrm{C}-(\mathrm{AA})+(\mathrm{DAP})+(\mathrm{TMA})$ & $81.25 \pm 25.6 b$ & 2.9 & 17.8 & 82.2 & 325 \\
\hline $\mathrm{D}-(\mathrm{AA})+(\mathrm{PT})+(\mathrm{TMA})$ & $134 \pm 72.96 b$ & 4.8 & 17.7 & 82.3 & 538 \\
\hline Computed (F) & 7.5 & & & & 929 \\
\hline Tabulated (F) at level $5 \%$ of 3.12 & & & 3.49 & & \\
\hline L.S.D. & & & 69.2 & & \\
\hline
\end{tabular}

Means followed by the same letters are not significantly different at $5 \%$ level.

Data presented in Table (2) show cumulated mean number of medflies (males and/or females) captured/trap/day; at the second period (December $22^{\text {th }} 2015$ - January $17^{\text {th }} 2016$ ). The climatic conditions recorded in this period, characterized by Avg, daily temperature $\left(13.8^{\circ} \mathrm{C}\right)$, and Avg. relative humidity $(\mathrm{RH}) \quad 54.9 \%$. The medfly population during this period was very low (191). Table (2) indicate mean weekly captures of $C$. capitata for treatments A-D. Despite the extremely low fly capture rate, the three component lure treatment (D) (AA + PT + TMA) was significantly more efficient than other tested treatments A and B. Treatment (C) (AA + DAP + TMA) showed light increase in captured flies when compared with other treatments A and B. Also, all baits showed marked selectivity for females. In the same time, data represented in Table (2) clearly show that the highest percentage of captured females at the second period was recorded in treatment (D) $76.5 \%$, while the highest percentage of captured males in treatment (A) was $50 \%$. Data show also there was non significant difference between treatment (D) and treatment (C), while there was significant difference in mean number of captured flies between treatment (D) and treatments (A and B), where the computed $(\mathrm{F})$ value was 4.4 and L.S.D. $=21.9$.

Data in the second location show response of Mediterranean fruit fly, $C$. capitata to different attractant materials when inspected under field conditions in valencia orange (citrus sinensis var. Valencia) at Aga district, Dakahlia Governorate. Data shown in Table (3) represent cumulated mean number of medflies (males and/or females) captured/trap/day; at the third period (February $29^{\text {th }}-$ March $28^{\text {th }}$ 2016). The climatic conditions recorded in this period, represented by Avg, daily temperature and Avg. relative humidity were $17.3^{\circ} \mathrm{C}$ and (RH) $61.5 \%$, respectively. The medfly population during this period was low (456). Makkar 
\& El-Abbassi traps: attracted both sexes of C. capitata in all treatments. Also, traps attracted more females than males. The highest cumulated mean number of captured/trap/day was $60.5 \pm 33.7$ in case of treatment D (AA + PT + TMA ).

Table 2. Mean number, CTD values and percentages of captured medfly adults (Males and/or females) inside Makkar \& El-Abbassi traps throughout a period of four weeks in navel orange at the second period (December $22^{\text {th }} 2015-$ January $17^{\text {th }} 2016$ )

\begin{tabular}{|c|c|c|c|c|c|}
\hline \multirow{2}{*}{ Treatments } & \multirow{2}{*}{$\begin{array}{c}\text { Means } \\
\pm \text { SD }\end{array}$} & \multirow{2}{*}{ CTD } & \multicolumn{2}{|c|}{$\%$ of captured medfly adults } & \multirow{2}{*}{$\begin{array}{c}\text { Total } \\
\text { of males and females }\end{array}$} \\
\hline & & & क & 0 & \\
\hline$\overline{A-(A A)}$ & $1.0 \pm 1.7 \mathrm{a}$ & 0.04 & 50.0 & 50.0 & 4 \\
\hline $\mathrm{B}-(\mathrm{AA})+(\mathrm{DAP})+(\mathrm{PT})$ & $5.0 \pm 1.2 \mathrm{a}$ & 0.18 & 35.0 & 65.0 & 20 \\
\hline $\mathrm{C}-(\mathrm{AA})+(\mathrm{DAP})+(\mathrm{TMA})$ & $7.75 \pm 3.6 \mathrm{ab}$ & 0.28 & 35.0 & 64.5 & 31 \\
\hline $\mathrm{D}-(\mathrm{AA})+(\mathrm{PT})+(\mathrm{TMA})$ & $34.0 \pm 24.3 \mathrm{~b}$ & 1.20 & 23.5 & 76.5 & 136 \\
\hline Computed (F) & 4.5 & & & & 191 \\
\hline Tabulated (F) at level $5 \%$ of 3.12 & & & 3.49 & & \\
\hline L.S.D. & & & 21.9 & & \\
\hline
\end{tabular}

Means followed by the same letters are not significantly different at $5 \%$ level.

Data in table (3) clearly show that the highest percentage of captured females at this period in treatment (B) was 95\%, while the highest percentage of captured males in treatment (D) was $10.3 \%$. Data show also that there were non significant differences between

treatments (A, B and C) while, there was significant difference in mean number of captured flies between treatment (D) and treatments (A, B and C), where the computed $(\mathrm{F})$ value was 3.8 and L.S.D. $=36.7$.

Table 3. Mean number, CTD values and percentages of captured medfly adults (Males and/or females) inside Makkar \& El-Abbassi traps throughout a period of four weeks in Valencia orange at the third period

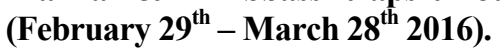

\begin{tabular}{lccccc}
\hline Treatments & $\begin{array}{c}\text { Means } \\
\pm \text { SD }\end{array}$ & CTD & \% of captured medfly adults & $\begin{array}{c}\text { Total } \\
\text { of males and females }\end{array}$ \\
\cline { 1 - 4 } A-(AA) & $8.5 \pm 4.3 \mathrm{a}$ & 0.30 & 5.9 & 9 & 34 \\
B-(AA) + (DAP) + (PT) & $15.0 \pm 6.7 \mathrm{a}$ & 0.54 & 5.0 & 95.0 & 60 \\
C-(AA) + (DAP) + (TMA) & $30.0 \pm 22.5 \mathrm{a}$ & 1.07 & 12.5 & 87.5 & 120 \\
D-(AA) +(PT) + (TMA) & $60.5 \pm 33.7 \mathrm{~b}$ & 2.16 & 10.3 & 89.7 & 242 \\
Computed (F) & 3.8 & & & & 456 \\
Tabulated (F) at level 5\% of 3.12 & & & 3.49 & \\
L.S.D. & & & 36.7 & & \\
\hline
\end{tabular}

Means followed by the same letters are not significantly different at $5 \%$ level.

Data presented in Table (4) show cumulated mean number of medflies (males and/or females) captured flies/trap/day; at the fourth period (March 30th - April 26th 2016). The climatic conditions recorded in this period, represented by Avg, daily temperature and Avg. relative humidity showed $20.1^{\circ} \mathrm{C}$ and $(\mathrm{RH}) 63.2 \%$, respectively. The medfly population during this period was high (1697).

Table 4. Mean number, CTD values and percentages of captured medfly adults (Males and/or females) inside Makkar \& El-Abbassi traps throughout a period of four weeks in Valencia orange at the fourth period (March 30 ${ }^{\text {th }}-$ April 26 ${ }^{\text {th }}$ 2016).

\begin{tabular}{lccccc}
\hline Treatments & $\begin{array}{c}\text { Means } \\
\pm \text { SD }\end{array}$ & CTD & \multicolumn{2}{c}{ \% of captured medfly adults } & $\begin{array}{c}\text { Total } \\
\text { of males and females }\end{array}$ \\
\cline { 1 - 2 } A-(AA) & $46.00 \pm 30.3 \mathrm{a}$ & 1.6 & 16.3 & 83.7 & 184 \\
B-(AA) + (DAP) + (PT) & $72.50 \pm 5.0 \mathrm{ab}$ & 2.6 & 13.1 & 86.9 & 290 \\
C-(AA) + (DAP) + (TMA) & $152.25 \pm 22.5 \mathrm{~b}$ & 5.4 & 12.5 & 87.5 & 609 \\
D-(AA)+ (PT) + (TMA) & $153.50 \pm 58.4 \mathrm{~b}$ & 5.5 & 7.8 & 92.2 & 614 \\
Computed (F) & 3.69 & & 3.49 & & 1697 \\
Tabulated (F) at level 5\% of 3.12 & & & 88.5 & & \\
L.S.D. & & &
\end{tabular}

Means followed by the same letters are not significantly different at $5 \%$ level.
Data revealed also that the highest percentages of captured females at this period was in treatment (D) $(92.2 \%)$, while the highest percentage of captured males in treatment $(\mathrm{A})$ was $16.3 \%$. There were non significant differences between treatments (A) and (B), likewise, there were non significant differences between treatments (B, C and D), while there were significant difference in mean number of captured flies between treatments $(\mathrm{C}, \mathrm{D})$ and treatments $(\mathrm{A}, \mathrm{B})$, where the computed (F) value was 3.69 and L.S.D. $=88.5$. Total
The highest cumulated mean number of captured/trap/day were $(153.50 \pm 58.4)$ and $(152.25 \pm 22.5)$ in case of treatments (D) (AA + PT + TMA ) and (C) (AA + DAP + TMA), respectively. Meanwhile, the lowest cumulated mean number of captured flies/trap/day was $(46.00 \pm 30.3)$ in case of treatment (A) (AA). number of $C$. capitata females captured inside Makkar and El-Abassi traps all over the period of experiment (16 weeks) are illustrated in (Fig. 1 and 2). Total number of captured medfly males and females were (1120 \& 2153). During the first and second location, respectively. Also figures 1 and 2 clearly show that the highest total number of captured females at the two locations in treatment (D) (AA + PT + TMA) were 547 and 783 flies during the first and second location, respectively. 


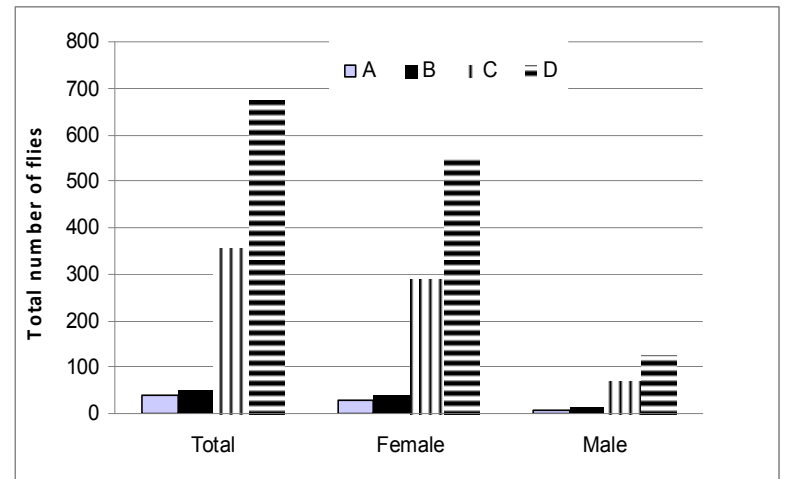

Fig. 1. Total cumulated number, males and females inside Makkar \& El- Abbassi traps at first location.

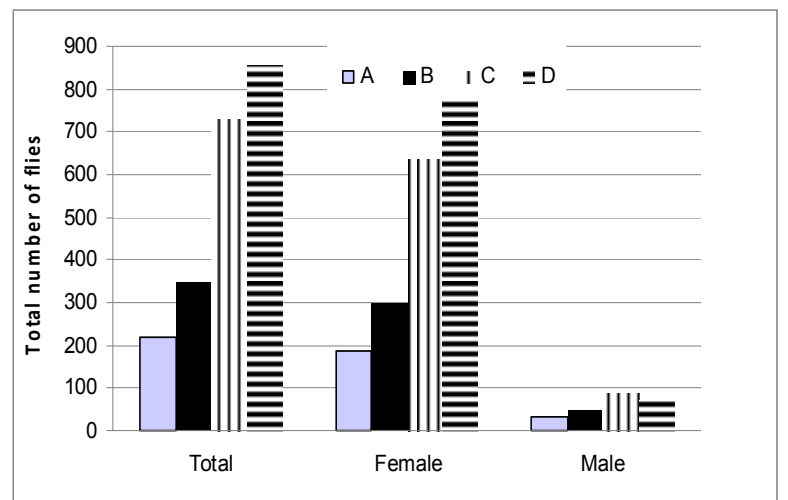

Fig. 2. Total cumulated number, males and females inside Makkar \& El-Abbassi traps at second location.

\section{DISCUSSION}

The present investigation showed that in all treatments both sexes of medfly were attracted, however females were more attracted than males. Similar results were obtained by (Alemany et al., 2004 and Braga Sobrinho et al., 2004). In this study, it was found that, all four treatments showed marked selectivity for females. This results coincides with the findings of (Manrakhan et al., 2017), who found that significantly more $C$. capitata females were trapped in three-component Biolure-baited Chempac Bucket trap (AA + TMA + PT) than in other lures (a combination of AA + TMA, a combination of AA + PT, torula yeast and Questlure in McPhail-type traps. In the same trend Ben Jemâa et al., (2010) found that the percentage of captured $C$. capitata females was significantly higher than that of males in mandarin and washengton navel orange orchards. Also this data in almost in agreement with the findings of Alemany et al., (2004) who found that mean percentage of $C$. capitata females captured in 125 traps placed in alternative trees using synthetic food attractants for females (ammonium acetate, puterscine and trimethylamine) was $79.3 \%$. However. in this study, data revealed that the highest percentages of captures females of the fourth period was in treatment (D) $(\mathrm{AA}+\mathrm{PT}+\mathrm{TMA})(92.2 \%)$. The present investigation showed that in all four periods there was non significant difference between treatment (D) (AA + Pt + TMA) and treatment (C) (AA + DAP + TMA). Similarly, Heath et al., (2004) and Leblanc et al., (2010) found non significant difference in number of captured $C$. capitata with ammonium acetate and trimethylamine alone or in combination with putrescine unless population levels were very low $(<1.0$ and 0.3 females per trap per day, respectively)

\section{CONCLUSION}

Results obtained revealed that the three components lure (AA +PT + TMA) in Makkar and El-Abassi plastic trap with retention system (Deltamthrine $0.2 \mathrm{mg}$.) was the most efficient in capturing flies in the two tested locations and could be used in mass trapping technique for controlling this insect pest. Results showed that Makkar and El-Abassi trap with three components lure (AA +PT + TMA), treatment (D) captured flies more than other treatments at the two tested locations. All four lures showed marked selectivity for females. Treatment (C) (AA + DAP + TMA) was more efficient in capturing flies when compared with treatments A (AA). Synthetic food lures are more species specific than liquid portion baits whilst still maintaining dual sex attraction. Moreover, the lack of water in tested lures reduces the catch rates of beneficial insects and trash flies (Epsky et al., 1999).

\section{REFERENCES}

Alemany, A.; Alonso, D.; and Miranda, M.A. (2004): Evaluation of improved Mediterranean fruit fly attractants and retention systems in the Balearic Islands (Spain). Pages 355-359. In Proceedings 6th International Symposium on Fruit Flies of Economic Importance, 6-10 May, 2004, Stellenbosch, South Africa.

Ben Jemâa, J.M.; Bachrouch, O.; El Allimi and , M.H. Dhouibi (2010).

Field evaluation of Mediterranean fruit fly mass trapping with Tripack as alternative to malathion baitspraying in citrus orchards. Span. J. Agric. Res., 8(2): 400-408.

Broughton, S. and Delima, C.P. (2002): Field evaluation of female attractants for monitoring Ceratitis capitata (Diptera: Tephritidae) under a range of climatic conditions and population levels in Western Australia. J. Econ. Entomol., 95: 507-512.

Braga-Sobrinho, R.; Lindemberg, A.; Mesquita, M.; Enkerlin, W.; Guimaraes, J. A.; TorresBandeira, C. and Alves-Peixoto, M. J. (2004): Evaluation of fruit fly attractants in the state of Ceara - Brazil. Revista Ciencia Agronomica 35: 253-258.1

Cohen, H. and Yuval, B. (2000): Perimeter trapping strategy to reduce Mediterranean fruit fly (Diptera: Tephritidae) damage on different host species in Israel. J. Econ. Entomol., 93,721-725.

El-Abbassi, T. S.; Makkar, A.W.; El-Metwally, M.M. and Ghanim, N.M. (2017): Field evaluation of some ammonium compounds when used at different combination ratios on attracting Med fly adults, Ceratitis capitata (Wied.) in citrus orchards. Bull. Ent. Soc. Egypt (in press).

Epsky, N. D. and Heath, R. R. (1998): Exploiting the interactions of chemical and visual cues in behavioral control measures for pest tephritid fruit flies. Florida Entomologist, 81: 273-282. 
Epsky, N.D.; Hendrichs, J.; Katsoyannos, B.I.; Vásquez, L. A.; Ros, J. P.; Zümreoglu, A.; Pereira, R.; Bakri, A.; Seewooruthun, S. I.; and Heath, R. R. (1999): Field evaluation of femaletargeted trapping systems for Ceratitis capitata (Diptera: Tephritidae) in seven countries, J. Econ. Entomol., 92:156-164.

Fletcher, B.S. and Prokopy, R.J. (1991): Host location and oviposition in tephritid fruit flies, p. 140-171, In W. J. Bailey and J. Ridsdill-Smith, eds. Reproductive Behaviour of Insects. Chapmann \& Hall.

Heath, R. R.; Epsky, N.D.; Dueben, B.D.; Rizzo, J. and Jermino, F. (1997) : Adding methyl-substituted ammonia derivatives to a food-based synthetic attractant on capture of the mediterranean and mexican fruit flies (Diptera: Tephritidae) . J. Econ. Entomol., 90 (6): 1584-1589

Heath, R.R.; Epsky N.D.; Midgarden D. and Katsoyannos, B.I. (2004): Efficacy of 1,4-diamino-butane (Putrescine) in a food-based synthetic attractant for capture of mediterranean and mexican fruit flies (Diptera: Tephritidae). J. Econ. Entomol., (97): 1126-1131.

Hull, C. D., and Cribb, B.W. (2001): Olfaction in the Queensland fruit fly, Bactrocera tryoni. I Identification of olfactory receptor neuron types responding to environmental odors. J. of Chemical Ecology, 27: 871-887.

Leblanc, L.; Vargas, R.I. and Rubinoff, D. ( 2010): Attraction of Ceratitis capitata (Diptera: Tephritidae) and endemic and introduced nontarget insects to BioLure bait and its individual components in Hawaii. Environ. Entomol.39: 989998.

Makkar, A.W.; El-Abbassi, T.; Abdel-maboud, A.S. and Anas, A.A. (2015): A field evaluation of Makkar and El-Abbassi trap and its modifications for attracting adult males of peach fruit fly, Bactrocera zonata (Saundress) in comparsion with Jackson trap. Bull. Ent. Soc. Egypt, Econ. Ser., 41: 161-174.

Makkar, A.W.; El-Abbassi, T.; Abdel-maboud, A.S.; Anas, A.A. and Shawer, D.M. (2016): Evaluating efficiency of of Makkar and El-Abbassi trap in attracting the the Mediterranean Fruit Fly, Ceratitis capitata Wied in field as alternative to standard traps. Bull. Ent. Soc. Egypt, Econ. Ser., 93:15-28.
Manrakhan, A.; Daneel, J.H; Beck, R.; Virgilio, M.; Meganck, K. and De Meye, M. (2017). Efficacy of trapping systems for monitoring of Afrotropical fruit Flies. J. Appl. Ent. doi: 10.1111/jen.12373.

Midgarden, D.; Ovalle, O.; Epsky, N.D.; Puche, H.; Kendra, P.E.; Rendon, P. and Heath, R.R. (2004). Capture of Mediterranean fruit flies (Diptera: Tephritidae) in dry traps baited with a food-based attractant and Jackson traps baited with trimedlure during sterile male release in Guatemala. J Econ. Entomol. 97, 2137-2143

Navarro-Llopis, V.; Alfaro, F.; Domı'nguez, J., Sanchis, J. and Primo, J. (2008): Evaluation of traps and lures for mass trapping of Mediterranean fruit fly in citrus groves. J. Econ. Entomol. 101:126-131.

Navarro-Llopis, V.; PriMo, J. and Vacas, S. ( 2012): Efficacy of attract-and-kill devices for the control of Ceratitis capitata. Pest Management Science. doi:10.1002/ps.3393

Papadopoulos, N.; Katsoyannos, B. I.; Kouloussis, N.A.; Hendrichs, J.; Carey, J. R. and Heath R.R. (2001): Early detection and population monitoring of Ceratitis capitata (Diptera: Tephritidae) in a mixedFruit orchard in northern Greece. J. Econ., Entomol., 94(4): 971-978 .

Piñero, JC; Souder, S.K.; Smith , T.R.; Fox , A.J. and Vargas, R.I. (2015): Ammonium acetate enhances the attractiveness of a variety of protein-based baits to female Ceratitis capitata (Diptera: Tephritidae). J Econ. Entomol. ;108(2):694-700.

Ros, J.P.; Castillo, E.; Wong, E. and Castro V. (1997): Trimetilamine: an effective promotor of Putrescine and amonium acetate attractants, tocapture Mediterranean fruit fly females Ceratitis capitata Wied. (Diptera, Tephritidae). Boletin de sanidad vegetal plagas (Oct-Dic 2005).

Tóth , M.; Nobili, P.; Tabilioer R. and Ujváry I. (2004): Interference between male-targeted and femaletargeted lures of the Mediterranean fruit fly Ceratitis capitata (Diptera., Tephritidae) in Italy. J. Appl. Entomol. 128: 64-69.

White I.M. and Elson-Harris MM. (1994) : Fruit flies of economic significance: Their identification and bionomics. CAB International. Oxon, UK. 601 pp.

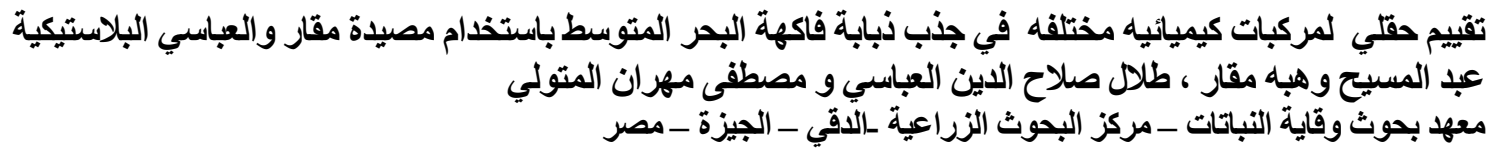

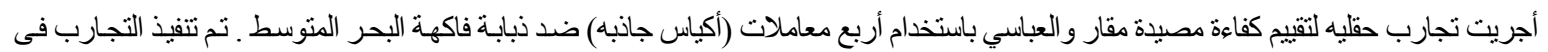

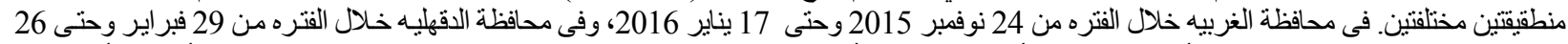

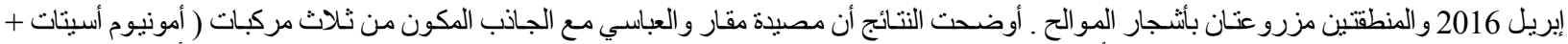

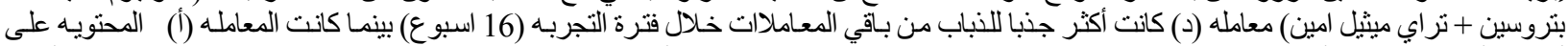

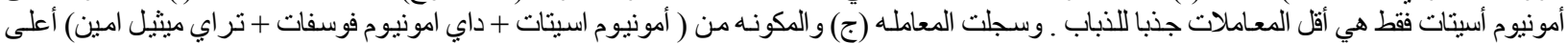

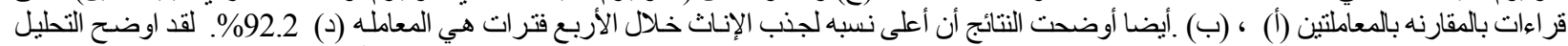

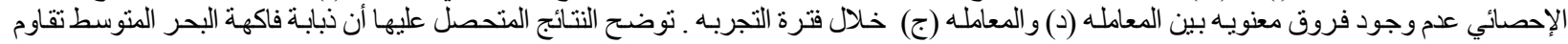
بو اسطة استخدام المصايد المكثفه وان المعامله (د) افضل المغل اختيار لنظام المصايد المكثفه. 